\title{
Development of an in vitro cleavage assay system to examine vaccinia virus I7L cysteine proteinase activity Chelsea M Byrd ${ }^{1}$ and Dennis E Hruby*1,2
}

Address: ${ }^{1}$ Molecular and Cellular Biology Program, Oregon State University, 220 Nash Hall, Corvallis, Oregon, 97331, USA and ${ }^{2}$ Siga Technologies, 4575 SW Research Way, Suite 230, Corvallis, Oregon, 97333, USA

Email: Chelsea M Byrd - cbyrd@sgph.com; Dennis E Hruby* - dhruby@sgph.com

* Corresponding author

Published: 16 August 2005

Virology Journal 2005, 2:63 doi:10.1 186/1743-422X-2-63

This article is available from: http://www.virologyj.com/content/2/l/63

(c) 2005 Byrd and Hruby; licensee BioMed Central Ltd.

This is an Open Access article distributed under the terms of the Creative Commons Attribution License (http://creativecommons.org/licenses/by/2.0), which permits unrestricted use, distribution, and reproduction in any medium, provided the original work is properly cited.
Received: 21 April 2005

Accepted: 16 August 2005

\begin{abstract}
Through the use of transient expression assays and directed genetics, the vaccinia virus (VV) I7L gene product has been implicated as the major maturational proteinase required for viral core protein cleavage to occur during virion assembly. To confirm this hypothesis and to enable a biochemical examination of the $17 \mathrm{~L}$ cysteine proteinase, an in vitro cleavage assay was developed. Using extracts of $\mathrm{VV}$ infected cells as the source of enzyme, reaction conditions were developed which allowed accurate and efficient cleavage of exogenously added core protein precursors (P4a, $\mathrm{P} 4 \mathrm{~b}$ and P25K). The cleavage reaction proceeded in a time-dependent manner and was optimal when incubated at $25^{\circ} \mathrm{C}$. 17L-mediated cleavage was not affected by selected inhibitors of metalloproteinases, aspartic acid proteinases or serine proteinases (EDTA, pepstatin, and PMSF, respectively), but was sensitive to several general cysteine proteinase inhibitors (E-64, EST, lodoacetic acid, and NEM) as well as the I7L active site inhibitor TTP-6I7I [C. Byrd et al., J. Virol. 78:12 I47-12156 (2004)]. Finally, in antibody pull down experiments, it could be demonstrated that monospecific $\alpha 17 \mathrm{~L}$ serum depleted the enzyme activity whereas control sera including $\alpha \mathrm{GIL}$, directed against the VV metalloproteinase, did not. Taken together, these data provide biochemical evidence that $17 \mathrm{~L}$ is a cysteine proteinase which is directly involved in VV core protein cleavage. Furthermore, establishment of this I7L-mediated in vitro cleavage assay should enable future studies into the enzymology and co-factor requirements of the proteolysis reaction, and facilitate antiviral drug development against this essential target.
\end{abstract}

\section{Background}

The Orthopoxviridae include vaccinia virus, camelpox, cowpox, ectromelia, monkeypox, raccoonpox, skunkpox, taterapox, volepox, and variola. Viruses in this family are the cause of numerous diseases including smallpox (variola), and recent human outbreaks of monkeypox. Orthopoxviruses are large double-stranded DNA viruses that are unique amongst DNA viruses in that they replicate exclusively within the cytoplasm of infected cells. Vaccinia virus (VV) is the most extensively studied virus in this group and is the prototypic member. The genome of $\mathrm{VV}$ is predicted to encode over 200 open reading frames. $\mathrm{VV}$ expresses its genetic information in three stages, as early, intermediate, and late genes. The early genes, which account for approximately half of the genome and are transcribed prior to DNA replication, encode many of the proteins involved in viral DNA replication and intermediate gene expression. The intermediate genes, of which only a handful have been identified, are expressed after the onset of DNA replication, and encode proteins that 
are activators of late gene expression. The late genes encode many proteins required for the transcription of early genes, the viral structural proteins and the enzymes necessary to process these proteins into their mature form.

Many viruses use proteolytic processing as a key step in their developmental cycle. RNA viruses and retroviruses commonly undergo formative proteolysis in which large polyproteins are cleaved by viral encoded proteinases to produce the structural and nonstructural proteins required for morphogenesis. DNA viruses such as poxviruses and adenoviruses commonly use another type of proteolysis, called morphogenic proteolysis where precursor proteins are first synthesized and then cleaved by viral proteinases to produce the mature form of the protein. The mature protein then plays an essential role in virion formation. During VV assembly, as the spherical immature virions (IVs) are maturing into the first infectious form of vaccinia virus, intracellular mature virus (IMV), a series of events takes place including proteolytic processing of viral core proteins [1-4].

Our laboratory has worked to identify and characterize the proteinases of VV in order to understand their regulation, function, and biochemistry, with a long term goal of developing inhibitors of these enzymes as antiviral drugs. The gene product of the I7L open reading frame recently has been suggested to be the core protein proteinase of $\mathrm{VV}$ through the use of an in vivo trans processing assay $[5,6]$. I7 $\mathrm{L}$ is an essential late gene, as shown through temperature sensitive mutant viruses $[7,8]$ and conditional lethal mutant viruses $[9,10]$ where under non-permissive conditions, viral morphogenesis is blocked prior to the formation of IMV. I7L is predicted to be a $47 \mathrm{kDa}$ cysteine proteinase that cleaves the major core protein precursors $\mathrm{P} 4 \mathrm{a}, \mathrm{P} 4 \mathrm{~b}$, and $\mathrm{P} 25 \mathrm{~K}$, products of the A10L, A3L, and L4R open reading frames respectively, at a novel Ala-Gly-Xaa cleavage site with cleavage occurring after the glycine residue $[5,6]$. I7 $\mathrm{L}$ also is likely to be responsible for cleavage of the A17 membrane protein, at an Ala-Gly-Ala site [9]. This consensus Ala-Gly-Xaa cleavage site of vaccinia is similar to that used for both the adenovirus and African swine fever virus proteinases which cleave after the second glycine in a Gly-Gly-Xaa motif $[11,12]$.

Comparative sequence analysis has suggested that the $\mathrm{VV}$ I7L proteinase is related to the ASFV and adenovirus cysteine proteinases and may form a new family of SUMO-1 related enzymes $[13,12]$. The nucleophilic cysteine is responsible for cleavage and is activated by the imidazol group of the catalytic histidine residue. Substrate specificity is determined by the substrate binding pocket and is unique for each proteinase. Several critical residues have been identified as being necessary for enzymatic activity of I7L including the catalytic triad residues [6].
Based on the identification of the catalytic residues and the predicted structure of the $\mathrm{I7L}$ proteinase, a new class of small molecule inhibitors was developed that are capable of inhibiting the replication of $\mathrm{VV}$, and were found to specifically target I7L through the generation of drug resistant mutant viruses with the mutations mapping to I7L [14].

To date, direct studies on the enzymology of I7L-mediated proteolysis have not been possible due to the absence of a suitable biochemical assay. In the experiments reported here, we describe the development of an in vitro I7L-mediated cleavage assay. We have used this system to obtain both biochemical and immunological data to prove that I7L is directly involved in cleavage of the major VV core protein precursors. Having this assay available will now facilitate biochemistry of the I7L enzyme and identification of all the required reaction components to be undertaken.

\section{Results}

To date, all studies of VV I7L activity have been carried out indirectly in transfected/infected tissue culture cells. Although this approach has provided some important insights into I7L biology, it is limited with respect to the study of I7L enzymology and identification of all the cis and trans factors required for substrate identification and catalysis. In order to approach these questions, we have sought to develop an in vitro cleavage assay for I7L. Thus far, the obvious approaches of expressing and purifying I7L from prokaryotic and eukaryotic expression vectors and combining with peptides or proteins containing a canonical A-G-X cleavage site have not been successful (data not shown), perhaps due to either the lack of essential co-factors or inappropriate assay conditions. As an alternative approach, we sought to develop a cleavage assay using infected cell extracts as the source of I7L activity and labeled core protein precursors made in vitro as the substrate. If successful, this system would provide the starting point for a dissection of the essential reaction components.

\section{In vitro Processing of Core Protein Precursors}

The three major core protein precursors $\mathrm{P} 4 \mathrm{a}$ (A10L), P4b (A3L), and P25K (L4R) which are known to be cleaved to a mature form (Figure 1) were cloned into plasmid vectors driven off of a T7 promoter to be used as a source of substrate for the assay. To investigate the ability of I7L to cleave the $\mathrm{P} 4 \mathrm{a}, \mathrm{P} 4 \mathrm{~b}$, and $\mathrm{P} 25 \mathrm{~K}$ substrates in vitro, we have used a system where the substrates are produced from an in vitro transcription and translation assay using rabbit reticulocyte lysates and then mixed with I7L expressed from virus infected cells. BSC40 cells are infected with ts16, a temperature sensitive mutant virus in which the responsible mutation maps to I7L. The virus infected cells 


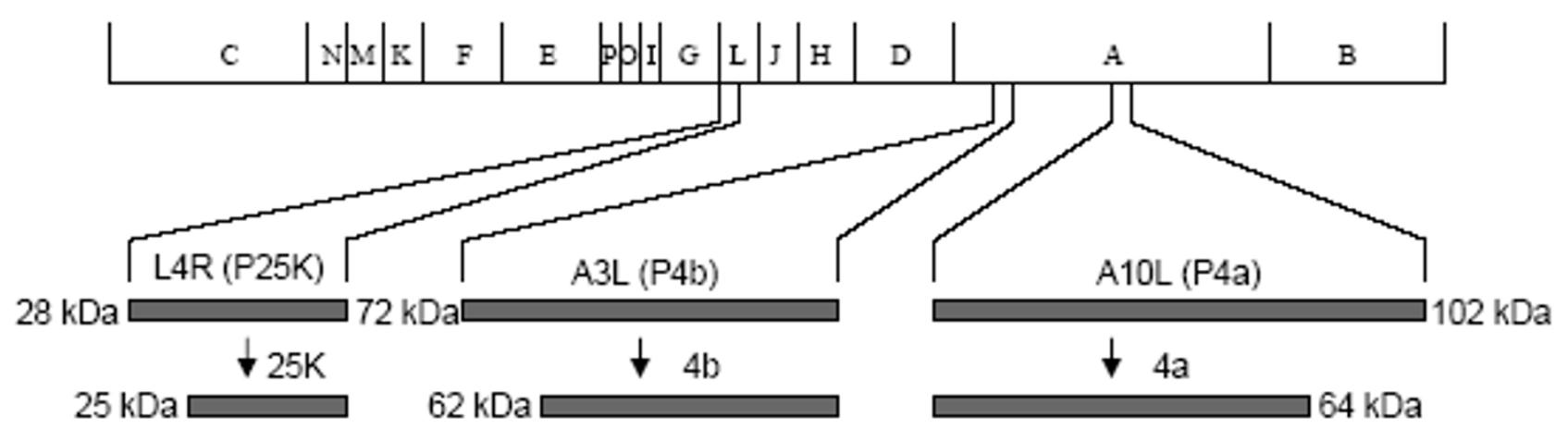

Figure I

Schematic representation of the major core protein precursor cleavage products. The vaccinia virus genome is represented depicting three of the major core protein precursors, the gene products of the L4R, AIOL, and A3L open reading frames, P25K, P4a, and P4b respectively. The precursors are shown being cleaved into their mature form. Molecular mass is indicated.

are incubated at the non-permissive temperature and transfected with plasmids expressing either wild-type I7L (pI7L) or I7L with the catalytic histidine residue mutated to an alanine (pI7LH241A). The extracts are prepared as described in the Materials and Methods. The extracts are mixed and incubated with the substrates for 3 hrs and then analyzed through SDS-PAGE and chemiluminescent detection. As shown in Figure 2, a specific band corresponding to unprocessed $\mathrm{P} 4 \mathrm{a}$ (top panel), $\mathrm{P} 4 \mathrm{~b}$ (middle panel), or P25K (bottom panel) is produced when the substrate is run alone. When mixed with cellular extracts, or extracts from cells infected with $t s 16$ at the non-permissive temperature and transfected with mutant $\mathrm{I} / \mathrm{L}$, no cleavage products are observed. However, when mixed with extracts from either cells infected with ts16 at the permissive temperature or cells infected with $t s 16$ at the nonpermissive temperature transfected with wild-type I7L, the cleaved products $4 \mathrm{a}, 4 \mathrm{~b}$, and $25 \mathrm{~K}$ are observed. Substrates with mutated A-G-X sites were not cleaved indicating that cleavage was occurring at the correct sites (data not shown). For the rest of the reported studies, P25K was used as the source of substrate since it gave the best cleavage profile.

\section{Processing Kinetics of Core Protein Precursors}

To determine the optimal temperature and kinetics of processing of the core protein precursors in the in vitro cleavage assay, a time course of I7L-mediated processing at various temperatures was performed. As shown in Figure $3 \mathrm{~A}$, at $0^{\circ} \mathrm{C}$, no processing was observed during the 20 $\mathrm{hr}$ time period. At $25^{\circ} \mathrm{C}$, a gradual increase in the amount of P25K cleavage product was observed starting at $15 \mathrm{~min}$ and increasing throughout the $20 \mathrm{hr}$ incubation period (Fig. 3B). Compared with the rate of cleavage at $25^{\circ} \mathrm{C}$, cleavage was slower at $30^{\circ} \mathrm{C}$ (Fig. 3C), starting around 30 min and increasing through the $20 \mathrm{hr}$ period, but never to the same level as at $25^{\circ} \mathrm{C}$. Processing is greatly reduced at $37^{\circ} \mathrm{C}$ with only a faint processed band ever appearing (Fig 3D).

\section{Influence of Thiol Reagents on the Protease Activity}

Based on its sequence similarity to the adenovirus protease, the African swine fever virus protease, and an ubiquitin-degrading enzyme in yeast, as well as the identity of a catalytic triad composed of histidine, cysteine, and aspartic acid, I7L has been classified as a cysteine proteinase. The thiol reagents dithiothreitol (DTT) and cysteine have been shown to enhance the cleavage activity of the adenovirus protease in an in vitro peptide cleavage assay [15]. To determine whether these agents have a similar effect on the activity of $\mathrm{I} 7 \mathrm{~L}$, they were added to the in vitro assay in a final concentration from 0-10 mM. However, no increase in cleavage activity was observed with the addition of either DTT or cysteine (data not shown). It is possible that once purified recombinant enzyme is produced these thiol reagents may increase its activity.

\section{Effect of Inhibitors on Protease Activity and Characterization as a Cysteine Proteinase}

The in vitro assay allowed us to test the effects of various protease inhibitors, as well as specific small molecule inhibitors on the activity of I7L. As shown in Figure 4 and 

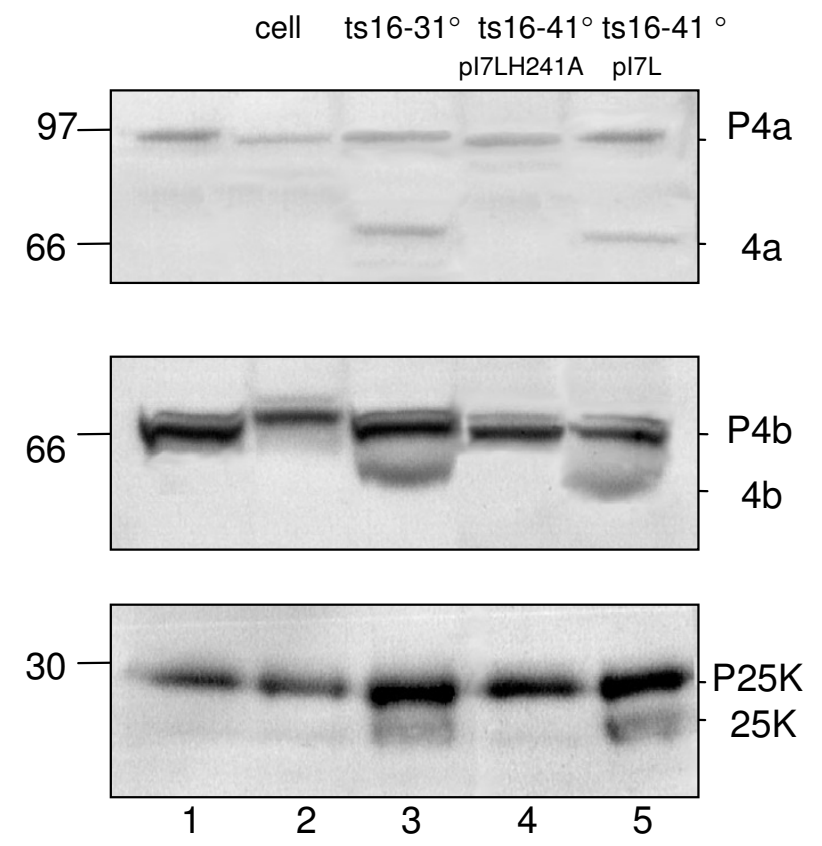

Figure 2

In vitro proteolytic processing of $\mathrm{P} 4 \mathrm{a}, \mathrm{P} \mathbf{4 b}$, and $\mathrm{P} 25 \mathrm{~K}$. I $\mu$ l of TNT produced substrate either P4a (A), P4b (B), or P25K (C) was mixed with $5 \mu$ l of Hepes buffer and I $4 \mu \mathrm{l}$ of enzyme extracts, either from uninfected cells, or cells infected with ts 16 at the permissive or non-permissive temperature. At the non-permissive temperature, plasmid borne I7L, either wild-type (pI7L) or mutant I7L (pI7LH24IA) was transfected in as the source of enzyme. The reaction was incubated at $29^{\circ} \mathrm{C}$ for $3 \mathrm{hrs}$ before being stopped by the addition of SDS sample buffer. Molecular weight is indicated on the left and the core protein precursor and product on the right. Lane $I$ is substrate alone, lane 2 is substrate mixed with cellular extracts and lanes 3-5 are substrate mixed with the enzyme extract indicated.

Table 1, the metalloproteinase inhibitor ethylenediaminetetraacetic acid (EDTA), the aspartic proteinase inhibitor pepstatin, and the serine proteinase inhibitor phenylmethanesulfonyl (PMSF) had no detectable effect on cleavage activity. The cysteine proteinase inhibitors iodoacetic acid (IA) and N-ethylmaleimide (NEM) efficiently blocked I7L mediated proteolysis of P25K. The cysteine proteinase inhibitors E-64 and EST were shown to inhibit protease activity at a relatively high concentration, but not at the lower concentration tested. This is consistent with what has been observed for both the adenovirus protease [16], and the African swine fever virus protease [17]. The failure of E-64 to inhibit protease activity at the lower concentration tested, and the location of the active site residues may suggest that each of these enzymes are not conventional papain-like enzymes, but

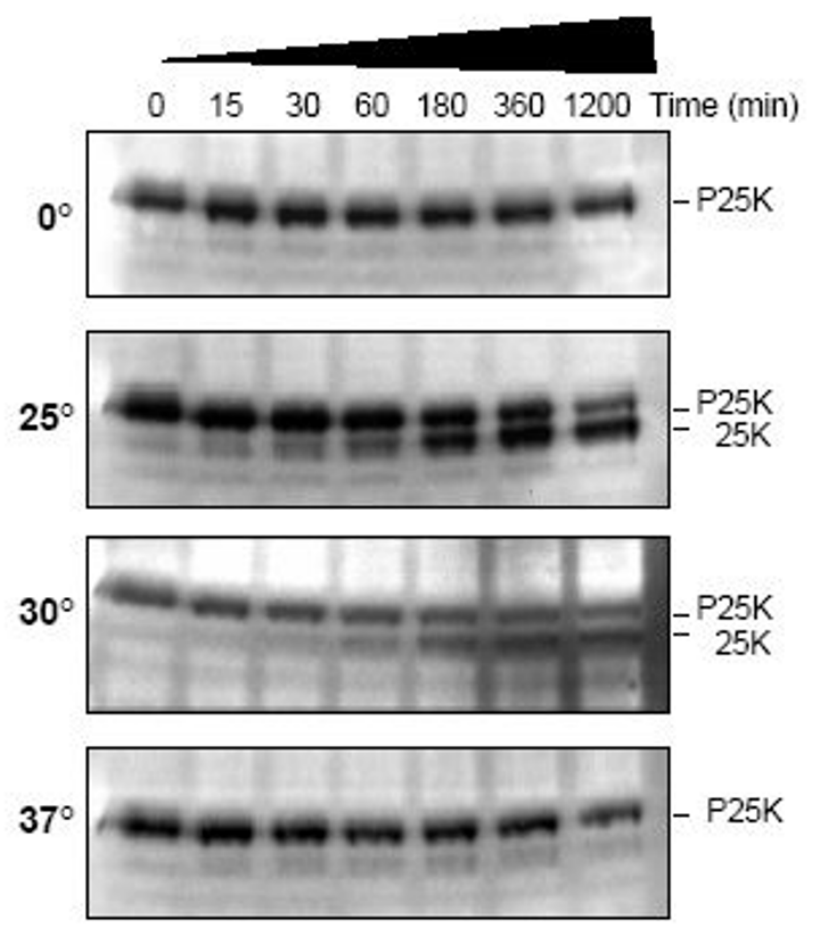

Figure 3

Processing kinetics of P25K. Samples were incubated at either $0^{\circ} \mathrm{C}(\mathrm{A}), 25^{\circ} \mathrm{C}(\mathrm{B}), 30^{\circ} \mathrm{C}(\mathrm{C})$, or $37^{\circ} \mathrm{C}$ (D) for up to 20 hrs, harvested at the indicated times and the reaction stopped by the addition of SDS sample buffer. Incubation temperature is indicated on the left and $\mathrm{P} 25 \mathrm{~K}$ precursor and $25 \mathrm{~K}$ mature product are indicated on the right.

may be a new family of cysteine proteinases. The cysteine protease inhibitor leupeptin also failed to inhibit protease activity, although this lack of inhibition was also observed with the adenovirus proteinase [16].

Next we wanted to determine if the small molecule I7L inhibitors previously developed as antiviral drug candidates [14] could be shown to specifically inhibit the activity of I7L in the in vitro assay. The compound TTP-6171 has been shown to inhibit viral replication in tissue culture, with drug resistant virus mutations mapping to I7L [14]. Here we see that this compound along with TTP1021, which was also found to inhibit I7L in tissue culture, inhibits the processing of $\mathrm{P} 25 \mathrm{~K}$ in vitro. However the compound TTP-0961, which was not found to generate resistant mutants in the $\mathrm{I7L}$ gene (data not shown), does not inhibit cleavage. These results demonstrate that this assay can be used for the screening of specific I7L 

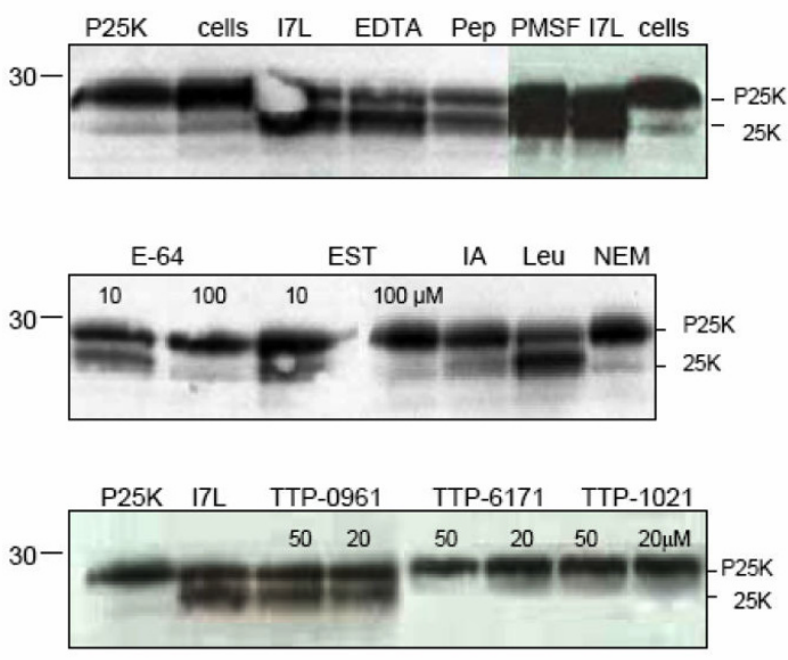

\section{Figure 4}

Effect of inhibitors on in vitro processing. Various concentrations of protease inhibitors were added to the in vitro processing assay for $6 \mathrm{hr}$ at $29^{\circ} \mathrm{C}$. The first lane is P25K expressed alone with no extract added. The second lane is P25K mixed with cellular extracts and the third lane is P25K mixed with I7L enzyme extracts. Each of the remaining lanes has P25K mixed with I7L enzyme extracts plus indicated inhibitor. Ethylenediaminetetraacetic acid (EDTA) was used at I mM. Pepstatin A, Pep, was used at $10 \mu \mathrm{M}$. Phenlymethanesulfonyl fluoride (PMSF) was used at I mM. N-(transEpoxysuccinyl)-L-leucine 4-guanidinobutylamide trans-Epoxysuccinyl-L-leucylamido(4-guanidino)butane (E-64) and a related product EST, were both used at $10 \mu \mathrm{M}$ and $100 \mu \mathrm{M}$ concentrations. lodoacetic acid (IA) was used at I mM. Leupeptin (Leu) was used at I mM, and N-ethlymaleimide (NEM) was used at $2.5 \mathrm{mM}$. The concentrations of TTP-6I7I, TTPI02I, and TTP-096I are indicated. The table indicates the concentration of inhibitor used and whether cleavage activity was observed.

inhibitors and confirms that this class of molecules targets I7L.

\section{Effects of I7L antibody competition on cleavage}

To directly demonstrate that the cleavage observed in the in vitro assay requires the presence of $17 \mathrm{~L}$, increasing concentrations of I7L specific antiserum were added to the enzyme extracts overnight, and then the complex was precipitated with Protein A sepharose beads to deplete the extract of I7L and any associated co-factors. As shown in Figure 5, both of the I7L antisera tested inhibited cleavage of P25K while an antiserum targeting a different $\mathrm{VV}$ gene product, G1L, did not inhibit cleavage.

\section{Discussion}

In this report, a cell-free transcription and translation system was used to develop an in vitro cleavage assay for the VV cysteine proteinase I7L. Proteolytic activity was obtained by co-expression of I7L in ts16 infected cells at the non-permissive temperature. Each of the major core protein precursors, $\mathrm{P} 4 \mathrm{a}, \mathrm{P} 4 \mathrm{~b}$, and $\mathrm{P} 25 \mathrm{~K}$, were shown to be cleaved to their mature products by $\mathrm{I7L}$ using the in vitro assay. Evidence that this cleavage is specific to I7L was shown through the fact that expressing a mutant form of I7L resulted in the inability to cleave the core protein precursors. Antibody pull down experiments with $\alpha \mathrm{I} 7 \mathrm{~L}$ supported the conclusion that $\mathrm{I7L}$ plays a direct role in the proteolytic reaction.

A time course of processing at various temperatures indicated that for this particular assay, the optimal temperature for the reaction to be carried out at is $25^{\circ} \mathrm{C}$ with processing beginning as soon as 15 minutes after addition of enzyme and increasing as time progresses. The cleavage reaction was never driven to completion and this may be due to a lack of replenishing co-factors or the enzyme may have been used up in the reaction. It was surprising that the optimal reaction temperature was $25^{\circ} \mathrm{C}$ instead of $37^{\circ} \mathrm{C}$ which is the optimal growth temperature for $\mathrm{VV}$ in cell culture. One possible explanation is that $\mathrm{I} 7 \mathrm{~L}$ is present at high concentrations in the extract and one can measure marginal activity at low temperature, whereas at higher temperatures other proteinases are activated which degrade the I7L enzyme.

Known cysteine protease inhibitors such as E-64, iodoacetic acid, and NEM were shown to inhibit the in-vitro cleavage reaction while the metalloproteinase inhibitor EDTA, the aspartic acid protease inhibitor pepstatin, and the serine protease inhibitor PMSF all failed to inhibit the cleavage reaction indicating that the enzyme responsible for cleavage is a cysteine protease. Interestingly the cysteine protease inhibitors leupeptin, and low concentrations of E-64 did not inhibit the reaction. These cysteine protease inhibitors were also not shown to be effective against either the African Swine Fever Virus protease [17] or the adenovirus protease [16], further providing support for the theory that these enzymes may form a new family of cysteine proteases that differ from papain-like cysteine proteases.

Of particular interest, the small molecule inhibitors designed to fit into the active site pocket of I7L and previously shown to inhibit viral replication [14], were found to be active in inhibiting the in vitro cleavage reaction described here. A related compound (TTP-0961) that was not found to map to I7L was not able to abolish cleavage. This indicated that this assay may be useful for high- 
Table I: Effect of inhibitors on in vitro processing.

\begin{tabular}{llll}
\hline Inhibitor & Name & Concentration & Inhibit Cleavage \\
\hline Metalloproteinase & EDTA & $1 \mathrm{mM}$ & No \\
Aspartic acid proteinase & Pepstatin & $10 \mu \mathrm{M}$ & No \\
Serine proteinase & PMSF & $1 \mathrm{mM}$ & No \\
Cysteine proteinase & E-64 & $10 \mu \mathrm{M}$ & No \\
& E-64 & $100 \mu \mathrm{M}$ & No \\
& EST & $10 \mu \mathrm{M}$ & Yes \\
& EST & $100 \mu \mathrm{M}$ & Yes \\
IA & $1 \mathrm{mM}$ & No \\
TTP inhibitors & $1 \mathrm{mM}$ & Yes \\
& Leupeptin & $2.5 \mathrm{mM}$ & Yes \\
& TTP-6171 & $50 \mu \mathrm{M}$ & Yes \\
& TTP-6171 & $20 \mu \mathrm{M}$ & Yes \\
& TTP-1021 & $50 \mu \mathrm{M}$ & Yes \\
& TTP-1021 & $20 \mu \mathrm{M}$ & No \\
\hline
\end{tabular}

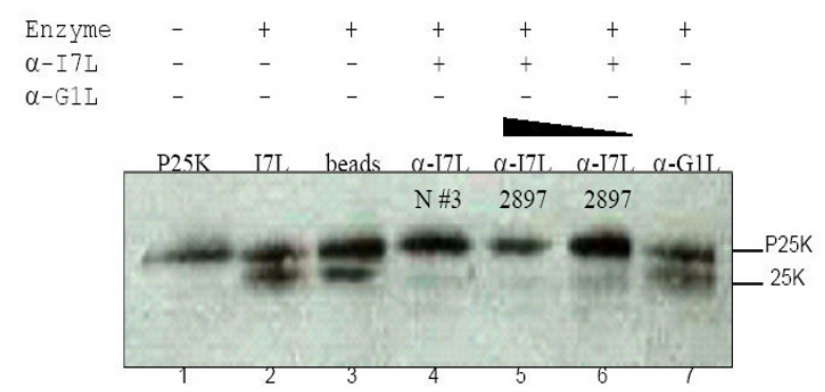

\section{Figure 5}

Effect of antibody competition on in vitro processing. Lane I is P25K expressed alone. Lane 2 is P25K mixed with I7L enzyme extracts. Lane 3 is P25K mixed with I7L extracts that have been diluted with Hepes buffer and treated with Sepharose beads. Lanes 4, 5, and 6 are P25K mixed with I7L extracts that have been incubated overnight with different I7L antiserum (indicated on each lane), treated with Sepharose beads and the antibody complex removed by centrifugation. Lane 7 is P25K mixed with I7L extracts incubated with GIL antiserum as above.

throughput screening of compounds to identify those that have specific activity for I7L.

\section{Conclusion}

Until this point, all work demonstrating that $17 \mathrm{~L}$ is the core protein proteinase has been done through transientexpression assays and the use of conditional lethal viruses in tissue culture $[9,5,6,10]$. The data obtained has indicated that I7L is essential for these processing activities, it did not rule out the possibility that some other factor or enzyme was also required for this activity to occur. Through the use of an in vitro assay we have shown that I7L is capable of cleaving the core protein precursors but that an additional co-factor is required for this activity to occur since expression of the enzyme through cell-free translation produced inactive enzyme. The co-factor(s) necessary for cleavage have yet to be determined. However, having the assay described in this report available will now enable a reductive analysis to be conducted to identify all the essential components of the reaction and to study their individual biochemical characteristics.

\section{Methods \\ Cells and Viruses}

BSC $_{40}$ cells [18] were grown in Eagle's minimal essential medium containing 5\% fetal calf serum (FCS) (Sigma, St. Louis, MO), $2 \mathrm{mM}$ glutamine (Invitrogen, Carlsbad, CA), and $15 \mu \mathrm{g} / \mathrm{ml}$ gentamicin sulfate (Invitrogen) in a $37^{\circ} \mathrm{C}$ incubator with $5 \% \mathrm{CO}_{2}$. Purified ts16 Vaccinia virus was prepared as described [19]. Escherichia coli strains were grown in Luria-Bertani broth or on Luria-Bertani medium containing $1.5 \%$ agar and ampicillin at $50 \mu \mathrm{g} / \mathrm{ml}$.

\section{Plasmids}

The A10L (P4a) gene was amplified by polymerase chain reaction using oligonucleotides KH10 (5' CATGCCATGGATGATGCCTATTAAGTCAATAGTTACT CTT-3') and KH11 (5'-CCGCTCGAGTTATTCATCATCAAAAGAGACAGAGTC-3'), digested with NcoI and XhoI, and cloned into the pTM1 vector, yielding pTM-P4a which utilizes a T7 promoter for expression. The A3L (P4b) gene was amplified using oligonucleotides KH08 (5'-CATGCCATGGATGGAAGCCGTGGTCAATAG-3') and KH09 (5'- 
TCCCCCGGGCTAAAAATAGTTCTGTAATAT-

GTCTAGCGCT-3'), digested with NcoI and SmaI, and cloned into the pTM1 vector to yield pTM-P4b. The L4R (P25K) gene was amplified using oligonucleotides DN51 (5'-CATGCCATG GATGAGTCTACTGCTAGAAAAC-3') and KH07 (5'-CCGCTCGAGTCAATCCTTT GTCG-3'), digested with NcoI and XhoI, and cloned into the pTM1 vector to yield pTM-P25K. The pI7L and pI7LH241A plasmids were described in Byrd et al., 2002 [5].

\section{Preparation of polyprotein or proteinase-containing extracts}

Confluent monolayers of $\mathrm{BSC}_{40}$ cells in 6-well plates were infected with ts $16 \mathrm{VV}$ at a multiplicity of infection of 2 plaque-forming units per cell and transfected with $2 \mu \mathrm{g}$ of plasmid DNA (either pI7L, or pI7LH241A) using DMRIE$\mathrm{C}$ (Invitrogen) following the manufacturer's indications. Infected cells were incubated either at the permissive temperature of $31.5^{\circ} \mathrm{C}$ or the non-permissive temperature of $39^{\circ} \mathrm{C}$. Cells were harvested at $24 \mathrm{~h}$ post-infection by pipetting up and down to lift the cells from the surface. The infected cells were centrifuged at $10,000 \times \mathrm{g}$ for 10 min, the supernatant was aspirated off, and the pellet was resuspended in $500 \mu \mathrm{L}$ homogenization buffer containing $20 \mathrm{mM}$ HEPES (pH 7.4), $0.28 \mathrm{M}$ sucrose, $2 \mathrm{mM}$ EDTA. This was passed through a 25-gauge syringe 15 times. The homogenate was centrifuged at $700 \times \mathrm{g}$ for $5 \mathrm{~min}$ to separate the nuclei and unbroken cells from the supernatant. The supernatant was centrifuged at $100,000 \times \mathrm{g}$ for $30 \mathrm{~min}$ at $4{ }^{\circ} \mathrm{C}$ to separate the membrane/particulate material from the supernatant. The supernatant was used as the source of enzyme.

Coupled TNT reactions with T7 RNA polymerase were performed according to the manufacturer's instructions (Promega Corporation, Madison, Wisconsin) as a source of substrate. Briefly, the TNT reactions were performed at $30^{\circ} \mathrm{C}$ in a final volume of $25 \mu \mathrm{L}$ with $1 \mu \mathrm{g}$ of plasmid DNA, using the non-radioactive Transcend label (biotinylated lysine residues are incorporated in the protein) provided with the kit for detection of protein.

\section{In vitro cleavage assay}

Reactions were performed at the indicated temperature in a final volume of $20 \mu \mathrm{L}$ containing $1 \mu \mathrm{L}$ of substrate, 13 $\mu \mathrm{L}$ of enzyme extract, and $6 \mu \mathrm{L}$ of $20 \mathrm{mM}$ HEPES (pH 7.4) buffer, $\mathrm{pH}$ 7.4. After the indicated times, the reaction was stopped by the addition of SDS sample buffer, and the samples were subjected to SDS-polyacrylamide gel electrophoresis. The results were analyzed by immunoblotting following the instructions provided by the TNT kit.

\section{Inhibitor studies}

For inhibitor studies, the reactions described above were incubated for $6 \mathrm{hr}$ in the presence or absence of the fol- lowing protease inhibitors: $1 \mathrm{mM}$ phenylmethanesulfonyl fluoride (PMSF) (Sigma), $10 \mu \mathrm{M}$ Pepstatin A (Sigma), 1 $\mathrm{mM}$ ethylenediaminetetraacetic acid (EDTA) (Sigma), 10 $\mu \mathrm{M}$ or $100 \mu \mathrm{M} \mathrm{N}$-(trans-Epoxysuccinyl)-L-leucine 4-guanidinobutylamide trans-Epoxysuccinyl-L-leucylamido(4guanidino)butane (E-64) (Sigma), $1 \mathrm{mM}$ iodoacetic acid (Sigma), $10 \mu \mathrm{M}$ or $100 \mu \mathrm{M}$ Leupeptin (Roche, Indianapolis, IN), $2.5 \mathrm{mM} \mathrm{N}$-ethylmaleimide (NEM) (Sigma). For I7L specific inhibition studies, the reactions described above were incubated for $6 \mathrm{hr}$ in the presence or absence of TTP-6171, TTP-1021, or TTP-0961 [14] at $5 \mu \mathrm{M}$ or 20 $\mu \mathrm{M}$ final concentrations.

\section{Antibody competition studies}

For the antibody competition studies, $25 \mu \mathrm{l}$ of I7L or G1L specific antiserum was added to $25 \mu \mathrm{L}$ of enzyme extract on a rotating shaker overnight at $4{ }^{\circ} \mathrm{C}$. ProteinA: Sepharose beads (Amersham Biosciences, Uppsla, Sweden) were added for $3 \mathrm{hrs}$ and the antibody complex was centrifuged to pull down the I7L enzyme. The supernatant was used as the source of extract in the in vitro assay described above. As a control, enzyme extract was mixed with buffer instead of antibody and treated with beads in a similar manner.

\section{Competing interests}

The author(s) declare that they have no competing interests.

\section{Authors' contributions}

$\mathrm{CMB}$ conceived the study, conducted all the experiments and wrote the manuscript. DEH coordinated the research efforts and edited the paper. Both authors read and approved the final manuscript.

\section{Acknowledgements}

We would like to thank Kady Honeychurch for constructing PTM:L4R, PTM:A3L, and PTM:AIOL, Rich Condit for providing ts 16, and TransTech Pharma for supplying TTP-6171, TTP-102I, and TTP-096I. This work was funded by NIH grant Al-060160.

\section{References}

I. Moss B, Rosenblum EN: Protein cleavage and poxvirus morphogenesis: tryptic peptide analysis of core precursors accumulated by blocking assembly with rifampicin. J Mol Biol 1973 , 81:267-269.

2. Silver M, Dales S: Biogenesis of vaccinia: interrelationship between post-translational cleavage, virus assembly, and maturation. Virology 1982, I 17:34I-356.

3. VanSlyke JK, Franke CA, Hruby DE: Proteolytic maturation of vaccinia virus core proteins: identification of a conserved motif at the $\mathbf{N}$ termini of the $4 \mathrm{~b}$ and $25 \mathrm{~K}$ virion proteins. J Gen Virol 1991, 72:411-416.

4. VanSlyke JK, Whitehead SS, Wilson EM, Hruby DE: The multistep proteolytic maturation pathway utilized by vaccinia virus P4a protein: a degenerate conserved cleavage motif within core proteins. Virology 1991, 183:467-478.

5. Byrd CM, Bolken TC, Hruby DE: The vaccinia virus $17 \mathrm{~L}$ gene product is the core protein proteinase. / Virol 2002, 76:8973-6. 
6. Byrd CM, Bolken TC, Hruby DE: Molecular dissection of the vaccinia virus 17L core protein proteinase. J Virol 2003, 77: | I279- II 283.

7. Ericsson M, Cudmore S, Shuman S, Condit RC, Griffiths G, Locker JK: Characterization of $t s 16$, a temperature-sensitive mutant of vaccinia virus. J Virol 1995, 69:7072-7086.

8. Kane EM, Shuman S: Vaccinia virus morphogenesis is blocked by a temperature-sensitive mutation in the 17 gene that encodes a virion component. J Virol 1993, 67:2689-2698.

9. Ansarah-Sobrinho C, Moss B: Role of the $\mathbf{1 7}$ protein in proteolytic processing of vaccinia virus membrane and core components. J Virol 2004, 78:6335-6343.

10. Byrd CM, Hruby DE: A conditional-lethal vaccinia virus mutant demonstrates that the $17 \mathrm{~L}$ gene product is required for virion morphogenesis. Virol J 2005, 2:4.

II. Webster A, Russell S, Talbot P, Russell WC, Kemp GD: Characterization of the adenovirus proteinase: substrate specificity. $J$ Gen Virol 1989, 70:3225-3234.

12. Andres G, Alejo A, Simon-Mateo C, Salas ML: African swine fever virus protease, a new viral member of the SUMO-I-specific protease family. J Biol Chem 200I, 276:780-787.

13. Li SJ, Hochstrasser M: A new protease required for cell-cycle progression in yeast. Nature 1999, 398:246-51.

14. Byrd CM, Bolken TC, Mjalli AM, Arimilli MN, Andrews RC, Rothlein $R$, Andrea T, Rao M, Owens KL, Hruby DE: New class of orthopoxvirus antiviral drugs that block viral maturation. J Virol 2004, 78: I2 I I7-I2I 56.

15. Webster A, Hay RT, Kemp GD: The adenovirus protease is activated by a virus-coded disulphide-linked peptide. Cell 1993, 72:97-104.

16. Webster A, Russell WC, Kemp GD: Characterization of the adenovirus proteinase: development and use of a specific peptide assay. J Gen Virol 1989, 70:3215-3223.

17. Rubio D, Alejo A, Rodriguez I, Salas ML: Polyprotein processing protease of African swine fever virus: purification and biochemical characterization. J Virol 2003, 77:4444-4448.

18. Raczynski P, Condit RC: Specific inhibition of vaccinia virus growth by 2'-O-methyladenosine: isolation of a drug-resistant virus mutant. Virology 1983, I28:458-62.

19. Hruby DE, Guarino LA, Kates JR: Vaccinia virus replication. I. Requirement for the host-cell nucleus. J Virol 1979, 29:705-15.

\section{Publish with Bio Med Central and every scientist can read your work free of charge}

"BioMed Central will be the most significant development for disseminating the results of biomedical research in our lifetime. "

Sir Paul Nurse, Cancer Research UK

Your research papers will be:

- available free of charge to the entire biomedical community

- peer reviewed and published immediately upon acceptance

- cited in PubMed and archived on PubMed Central

- yours - you keep the copyright

Submit your manuscript here:

http://www.biomedcentral.com/info/publishing_adv.asp
BiolMedcentral 